\title{
An intimate relationship in the shadow of narcissism: What is it like to live with a narcissistic spouse?
}

Määttä, Marju

Rovaniemi University of Applied Sciences, Finland (marju.maatta@gmail.com)

Uusiautti, Satu

University of Lapland, Finland (satu@uusiautti.fi)

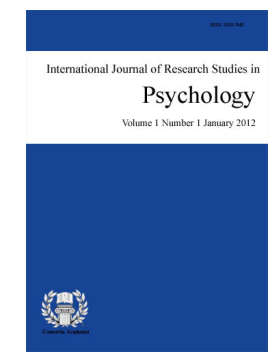

ISSN: $2243-7681$ Online ISSN: 2243-769X

OPEN ACCESS

University of Lapland, Finland (Kaarina.Maatta@ulapland.fi)

\section{Abstract}

Narcissistic personality disorder was recognized as a mental disturbance in the U.S. in 1980 . Typical characteristics of narcissism are, among others, the illusions of one's own omnipotence, an excessive need for admiration, as well as ruthless manipulation of the others. The purpose of this study is to describe the life in the shadow of narcissism, as a narcissist's spouse. The research problems are 1) how a narcissistic person is defined by his/her spouse and 2) what kind of model of the narcissistic behavior in an intimate relationship can be constructed? The qualitative data in this research was collected from a platform at the website of the Registered Association for Support for the Victims of Narcissists in Finland. The data consisted of 100 chains of messages (326 pages, 254 pseudonyms). The research data was analyzed with inductive content analysis. According to the victims' stories and experiences, narcissistic persons appear as unstable and immoral exercisers of power and manipulators who lack the sense of reality. Based on the results, the origin of these problems is in low self-esteem. The research results show how narcissism affects intimate relationships in many destructive ways.

Keywords: narcissistic personality disorder; narcissism; victim; intimate relationship; self-esteem 


\section{An intimate relationship in the shadow of narcissism: What is it like to live with a narcissistic spouse?}

\section{Introduction}

Narcissism is a personality disorder which is perceptibly common (Hare, 1993; Joutsiniemi, Kaulio, Mäkelä, Pekola, \& Schulman, 2007; Välipakka \& Lehtosaari, 2007). Narcissistic personality disorder belongs to the same group with unstable personality disorder and asocial personality disorder (Vaknin, 1999). Still, a small proportion of narcissism is necessary for survival in life (Crompton, 2007). Healthy narcissism has to be seen separate from narcissistic personality disorder. Healthy narcissism means for example the ability to have all kinds of feelings and be empathetic. Thus, healthy narcissism is based on true self-esteem that the narcissists totally lack (Hotchkiss, 2005.) Put shortly, narcissism turns into illness when it affects human relationships and healthy narcissism negatively (Ryynänen, 2008).

According to Vaknin (1999), narcissistic personality disorder is not a familial disease. It is not restricted only to certain age, occupational, or social class nor does it follow cultural boundaries. Narcissism may sneak insidiously in someone's life both at school, work or in an intimate relationship. Consequently, life in the shadow of narcissism is everyday life for some people. One narcissist is surrounded by even dozens of afflicted people and this makes the problem big.

Recently, narcissism has got increasingly attention from researchers; however, we still know little about what narcissists actually do in their everyday lives (Hotlzman, Vazire, \& Metlz, 2010) or in their intimate relationships (Määttä, 2009). Furthermore, it is often difficult to recognize the narcissist because he/she can act all emotional states in a credible way (Ellilä, 2008).

In this article, we contemplate how narcissism is connected to love. Of course, narcissism is the ultimate manifestation of self-love - or merely, it is a skew version of love. But how does narcissism affect an intimate or romantic relationship, then? In this article, we will describe how narcissism reflects and what it is like to live with a narcissist in an intimate relationship. The theme is ethically demanding and drawing an objective picture of the reality is not easy. Yet, one kind of reality can be achieved through narcissists' spouses' stories and experiences. The data in this research covers stories gathered from a platform at the web site of the Registered Association for Support for the Victims of Narcissists.

\section{Theoretical background}

\subsection{The concept of Narcissism}

The conversation about narcissism has become a part of our daily speech. The world and era that we are living has been called narcissistic, hard, and remorseless. In the colloquial language, we consider a narcissist as a histrionic, self-centered, and egoistic person (Myllärniemi, 2005). Although the word 'narcissism' is familiar to most people, we still are uncertain of its fundamental meaning.

Furthermore today, narcissism is widely seen as a continuum from healthy self-esteem to severe narcissistic pathology (e.g. Watson, Sawrie, Greene, \& Arredondo, 2002). In addition, the wide related terminology makes it more difficult to understand the phenomenon. Narcissism as a concept is linked to for example narcissistic disorder, narcissistic character disorder, narcissistic personality disorder, classic and borderline narcissistic disorder, psychopathy, and self-damage (Välipakka \& Lehtosaari, 2007). However, narcissism does have an accurate definition that describes how we live and take care of our human relationships and thus, narcissism is a concept with can be used to recognize and characterize the basic characteristics that define human nature and 
personality (Crompton, 2007).

Narcissism means self-love, self-admiration, and unrealistic illusions about one's own greatness. Narcissism may also refer to narcissistic personality disorder that has certain criteria for diagnosis. (Joutsiniemi et al., 2007.) The concept of narcissism originates in Classical Greek: according to the Greek Myth, Narcissus means love for a mental picture created about oneself (Vuorinen, 1998). Later on, Sigmund Freud introduced the concept among the concepts of psychology and psychiatry by his 1914 essay "On Narcissism". Freud self has told that he borrowed the term from Paul Näcke who used "narcissism" already in 1899 to describe men who were sexually excited by their own bodies but Freud expanded the term to include all kind of self-love and self-appreciation (Freud, 1993; Myllärniemi, 2005).

\subsection{Narcissism as a personality disorder}

People have the freedom and right to have unique personalities. However, such health-related factor that harms its bearer or his/her environment is defined as an illness, flaw, disability, handicap, or disorder. Often, this kind of feature makes it difficult or hinders from engaging to balanced human relationships or working. Personality disorder means an adulthood compulsive behavioral model and way of being disposed toward oneself and others. The behavior of people with personality disorder is long-lasting, inflexible, and relatively stable. Often, it is also rooted deeply in one's life style. This kind of person seems just incapable of acting differently (Joutsniemi et al., 2007; Välipakka \& Lehtosaari, 2007).

A person with personality disorder suffers from dysfunction that diminishes his/her viability (Rusz, 2007) and it has quite a specific and rigorously defined meaning (Crompton, 2007). Narcissism is mental dysfunction that belongs to personality disorders. In order to be defined as narcissism, behavior must diverge greatly in relation to other people's ways of thinking, feeling, and taking others (Joutsiniemi et al., 2007; Välipakka \& Lehtosaari, 2007). According to Hare (1993), narcissism is a syndrome, a combination of certain symptoms. Nine criteria have been defined to narcissistic personality disorder or narcissism. To be diagnosed as a narcissist, one has to have five of the following symptoms:

1. The person has high-flown illusions about his/her superiority and greatness. The person regards himself/herself especially important and great. For example, he/she exaggerates his/her talents, gifts, and achievements and simultaneously demands that everyone recognizes his/her supremacy and invincibility.

2. The person has compulsive fantasies about unlimited success, reputation, and omnipotence. He/she fantasizes about splendors and power beyond compare.

3. The person thinks of being so unequaled that only rare and special people are worth of his/her company or can understand him/her.

4. The person demands unreasonable amounts of admiration, idolatry, interest, and attention.

5. The person is deeply convinced that he/she is privileged and the same rules and norms that concern others do not concern him/her. He/she demands special and unique treatment.

6. The person ruthlessly exploits other people for his/her own good.

7. The person totally lacks empathy. He/she is not able or willing to pay attention to other people or their needs and feelings.

8. The person behaves contemptuously and impudently. He/she feels like being superior, omniscient, invincible, and above the law. He/she gets furious when facing resistance or when other inferior people reproach to him/her. 
9. The person envies other people all the time simultaneously thinking that others envy him/her. He/she suffers from paranoid illusions because he/she thinks that others act in the same way as he/she does (see Vaknin, 1999).

All the problems in narcissism can be seen to be somehow connected to a skew self-impression (Keltinkangas-Järvinen, 1985) - to some extent. On the other hand, it has been claimed that a narcissist's personality is not developed or strong enough to maintain a stable impression of himself/herself that would correspond the reality (Keltinkangas-Järvinen, 1978) while some recent studies (e.g. Carlson, Vazire, \& Oltmanns, 2011) have found out that narcissists' meta-perceptions of their personality correspond to reality: "Narcissists already realize that they are narcissistic and have a narcissistic reputation" (Carlson, Cazire, \& Oltmanns, 2011, p. 199). This assumption represents narcissistic awareness view while the narcissistic ignorance view (Gosling, John, Craik, \& Robins, 1998) narcissists believe that others see them just as positively as they see themselves.

Narcissistic personality disorder is one of the forms of narcissistic character disorders. Other character disorders that belong to the same group are asocial personality disorder, histrionic personality disorder, and unstable personality disorder. Considerable overlap occurs between narcissistic character disorders. Altogether, about 7-9 \% of the population has this kind of disorder. Among men, the frequency is around 11-18\% (Schulman, 2005a). It has been estimated that of 0.7-1\% of the population have pathological or permanent narcissistic personality disorder. Even $75 \%$ of narcissists are supposedly men (Vaknin, 1999). Yet, singular or temporary narcissistic symptoms or features may occur in everyone at some phase of life, for example in situations that are perceived threatening but these kinds of characteristics are usually momentary and not dominating enough for making a diagnosis (Joutsiniemi et al., 2007). What is common to all above-mentioned narcissistic character disorders is self-centeredness and ignoring other people (Schulman, 2005a). The number of symptoms and seriousness vary individually according to the seriousness of the narcissistic character disorder (Välipakka \& Lehtosaari, 2007).

In addition to character disorders, narcissists often suffer from the hidden feeling of inferiority, self-detracting attitude and shame. Narcissistic personality disorder may also involve psychotic-level serious depression, eating disorders, anti-social behavior, and drug-dependency. Narcissistic personality structure has indeed developed so that the narcissistic person should not have to consciously experience disheartening emotions such as inferiority, helplessness, guilt, or dependency. Often people who live with the narcissist have to experience these emotions instead of the narcissist. In reality, narcissists are, however, deeply traumatized. They "suffer" because their human relationships do not go as expected. If their exterior collapses, they do not bare the situation but may even end up committing suicide. Nevertheless, narcissists will not collapse easily because more often than not, they do not recognize or admit their problems (Schulman, 2005b).

\subsection{Narcissism and intimate relationships}

There is some research on narcissists' intimate relationships or how narcissism affects human relationships that should be introduced here as they help understanding the descriptions of the life in the shadow of narcissism. Narcissism is manifested in specific non-reciprocal relationships where there is not room for real partnership and cooperation. Žvelc (2010) divides human relationships into subject and object ones. Subject relationship means an intimate relationship where the partners are treated as individual subjects with their wishes, interests, and needs. The latter relationship type refers to such a relationship where the other is perceived as an object for the satisfaction of the first person's needs; thus, the object person has the only value according to whether he/she can satisfy the first person. Žvelc distinguishes three dimensions of object relations: dependence, alienation, and self-absorption. Narcissism and egocentrism are sub-dimensions of self-absorption.

When it comes to human relationships and ability to love and care, it is worth pointing out that narcissism is linked to emotions and empathy (Hartmann, 2009). Also Fan et al. (2010) have come to a conclusion that 
Intimate relationship in the shadow of narcissism: What is like to live with a narcissistic spouse?

narcissism may consequently be closely related to changes in inter-subjective relationships to other persons. Narcissists are unable to feel empathy when empathy is understood as an empathic stance where we are constantly trying to experience the inner state of the other and if possible, convey that understanding through our actions (Geist, 2009).

Self-centeredness in narcissism may seem like self-love which makes an impression of good self-esteem. In reality, a narcissist's self-esteem is almost non-existent. Because of low self-esteem, a narcissist is extremely sensitive, easily hurt, and does not tolerate criticism toward himself/herself whatsoever. However, this kind of sensitivity does not refer to sensitive emotional life but springs up if the narcissist's feeling of omnipotence becomes hurt. Furthermore, this sensitivity will never reach other people or their feelings. All in all, relationships with other people represent only various dependency and rewarding relationships: other people have instrumental value and they are means to regulate the narcissist's own moods (Keltinkangas-Järvinen, 1998).

Since narcissists' self-esteem is contingent on contextual factors, it is fragile and threatened when communicating with other people (see e.g. Burton \& Hoobler, 2011). Narcissists behave more aggressively than so-called normal people (Penney \& Spector, 2002) but it has also been demonstrated that narcissists are only aggressive when provoked (Baumeister, Bushman, \& Campbell, 2000). However, in object relationships, where narcissists perceive their partners as objects, they are likely to be provoked to aggressive behavior easily (e.g. Žvelc, 2010).

Intimate relationships and the reason to enter into one have also been studied from narcissists' point of view. Campbell (1999) suggests that narcissistic romantic attraction can be defined by three elements: an attention to the self, a lack of intimacy, and a related strategy for enhancing the self. According to Campbell's self-orientation model of narcissism, narcissists look for perfection more than caring in their romantic partners. Narcissists may become involved in romantic relationships that lack intimacy, while at the same time enhancing their self-esteem by means of association. Secondly, narcissists may display communication patterns within the context of romantic relationships that are aggressive and self-centered. Furthermore, narcissists are likely to be attracted to perfect non-caring others not only because they view these kinds of individuals as sources of self-esteem, but also because they seem similar to narcissists. All in all, narcissists are more romantically attracted to others who offer the potential to enhance the self by means of identification and admiration. Taken this starting point, it seems interesting to study what it is like to live with a narcissistic spouse.

\section{Research purpose}

A narcissistic person's behavior can be described as knock-down to its victim with the purpose of removing and destroying the victim's human dignity, self-esteem, balance, and happiness (England, 2007). Although only a fraction of the population has been diagnosed with narcissistic personality disorder, narcissism is more common and becoming more common all the time (Vaknin, 1999). The explanation for the increase in narcissistic disorders may at least partly be found in societal development as competitiveness, individualism, and opportunism are admired - those exact features that are often typical of narcissists (Myllärniemi, 2006).

The purpose of this study is to describe the life in the shadow of narcissism, as a narcissist's spouse. The research problems are as follows:

1. How a narcissistic person is defined by his/her spouse and;

2. What kind of model of the narcissistic behavior in an intimate relationship can be constructed?

\section{Research methodology}

The research approach in this research was qualitative because the main interest was focused on the stories and experiences of narcissists' spouses. The phenomenon studied thus represents multidisciplinary research on human relationships which make a complicated research target suitable for being addressed with the qualitative 
research approach (Acock, van Dulmen, Allen, \& Piercy, 2005). In this kind of research, the researchers aim to reach research participants' point of view, their personal and unique perception about the select phenomenon. In addition, the purpose is to study the features of the reality in their original form as far as possible (Kiviniemi, 2001).

In a qualitative research, the research target is comprised of people who act as personal subjects. The data was collected from the open web site of the Registered Association for Support for the Victims of Narcissists. The platform is divided into seven forums that cover various topics. The data for this research was collected from a platform called "Intimate relationship - General topics". All seven forums view narcissism from slightly different points of view. One covers men's experiences, one is about narcissists' children, and one about work communities. For this research, the one that covered intimate relationships was considered the most suitable for data collection. The research started in 2008 when the first author of this article collected altogether 50 conversation chains from the forum. These posts were dated between 5 March and 20 April 2008. In order to extend the data and draw more comprehensive picture about the theme, other 50 conversation chains were collected from the forum, dated between 26 February and 18 October 2009. Altogether the data comprises 100 conversation chains -326 pages as a transcript. One conversation chain could include dozens of messages and comments and therefore the number of pages is considerably larger than the number of conversation chains.

The participants' identity is not known. Total anonymity was possible because participants did not use their real names but pseudonyms when writing in the platform. These ready pseudonyms were also used when analyzing the data and with the exemplary quotations selected in the result section. Altogether 254 pseudonyms occurred in the research data. It is not possible to know whether each pseudonym refers to a different people: therefore, the number of participants is unknown, only the number of pseudonyms. Moreover, because of pseudonyms, it is impossible to know the proportion of men and women in the data or which age cohort the participants belong to. Many pseudonyms refer to a female respondent while a few to a male one but most of the pseudonyms were neutral in that sense.

We have added some citations from the data and they include the original pseudonym. If the pseudonym was a clear Finnish word, we have added a translation within square brackets. It also worth noticing that in Finnish language, there are not any separate words for women and men (as there are he and she in English) and therefore, if the author's gender was not recognizable based on the text or pseudonym, we had to use the expressions 'he/she' when translating the citations from the data.

The data analysis was qualitative content analysis. Tuomi and Sarajärvi (2002) describe content analysis as a tool for analyzing documents systematically and objectively. This method aims at drawing a condensed and general description of the phenomenon studied. When analyzing texts with content analysis, the focus is on the search of meanings in the text. In practice, the analysis proceeded by dividing the simplified expressions into five main categories: the exercise of power, maladjustment, immorality, lack of the sense of reality, and need for manipulation. Based on the main categories, a core category was created "Problems in self-esteem".

\section{Results}

The core category that emerged from the data was the problems in self-esteem. According to the data, the exercise of power, maladjustment, immorality, lack of the sense of reality, and need for manipulation appeared as manifestations of serious problems in self-esteem (Määttä, 2009). Self-esteem is a salient part of personality affecting the functioning of one's ego. Self-esteem includes the feelings of self-respect, self-appreciation, self-acceptance, and self-proficiency. Furthermore, the desire for self-esteem results from a fundamental need for psychological security, which is engendered by people's awareness of their own vulnerability and mortality (Greenberg, 2008). According to the victims' stories, narcissists seem to have problems in all these sectors. They reflect in narcissists' behavior, presence, and emotional life. From this basis, the problems in self-esteem may be considered as a core reason for narcissistic behavior. Next, we will review the core category in more detail by 
dissecting its connectedness with the main categories.

\subsection{The Exercise of Power}

The main category of the exercise of power consisted of the following elements: incrimination, subordination, controlling, naming, intimidation, raving, and physical violence. Abusing the significant other covers all such behavior that aims at controlling and repressing the other using fear, humiliation, shame, and verbal and physical insults as weapons (Forward \& Torres, 1989). This kind of behavior may be a sign of various dysfunctions in self-esteem. For narcissists with problems in self-esteem, becoming dumped or a threat of becoming dumped means an extreme insult. They may want to retaliate against the insult and injustice with violence.

"The usual pattern here is also that the narcissist does something that he realizes is wrong; gets feedback for it 'that was wrong' - so what do you know - all the sudden he blames someone else for it and demands apology because he has been hurt." (Minttumaaria [MintMary])

Narcissists who suffer from dysfunctions try to prove their omnipotence by using other people and thus strengthen their low self-esteem. The victim should be and act according to the narcissistic person's mind. The narcissistic partner watches, manipulates, and controls his/her victim, victim's mind, feelings, words, and acts. If the victim does not obey, he/she will be punished. Questioning the narcissist's omnipotence triggers off aggressive behavior (see also Keltinkangas-Järvinen, 1998).

"The narcissist's blanket comes out from the blanket cover and he/she asks me for help by saying: 'Would you like to put my blanket cover in place again?' Would you like to?! $\rightarrow$ By this little utterance, he/she constantly tries to tell that he/she is doing me a favor as he/she gives me the joy of serving him/her" (Beatbag)

"Serving and serving, invisible presence. I am not allowed to be seen or heard but service has to go well or else." (Mammu)

"He also reads my text messages regularly and checks my telephone calls. I feel like being a prisoner in my own life... I'm not allowed to meet any of my friends either... He wants to dominate and control me." (Wera79)

Narcissists are afraid of becoming abandoned and left alone. Those thoughts cause them feelings of helplessness and anxiety and they express these feelings to their victims through hatred (Malinen, 2007.) Aggression may occur as physical or mental violence that involves subjugation, intimidation, or raving among others (Keltinkangas-Järvinen, 1998).

"He/she raged and made noise that he/she will beat to death because he/she hates me so much" (Possu [Piggy])

"My ex made clear that he/she would assault my mother who is already an old woman. He/she would beat her so badly that I could not stand it. He/she intimidated and threatened to hurt even our children if I left." (Oodes)

“... I have a lifetime scar, still stitched, bite marks on my cheek; I thought I would be strangled.” 
Määttä, M., Uusiautti, S., \& Määttä, K.

(Mamax2)

Narcissists find it difficult or even impossible to tolerate their own flaws. When trying to handle their own deficiencies, they look for them in other people and tend to highlight them by despising. According to this research, it seemed typical that narcissists blame their victims for their own flaws. When spouting to their victims with invectives, narcissists end up listing all their own hidden and dread sides.

“I am just a sleaze who ruins everyone else's life.” (Susb)

"The narcissist gave me a night gown as a present and regretted to say that he could not find any larger size from the store. The gown was size XXXXL... my size was M/L." (Onnitar [Ms Fortune])

\subsection{Maladjustment}

The main category of maladjustment included such features as self-centeredness, volatility, lack of empathy, insensitivity, intolerance of criticism, and inability of intimacy. Self-centeredness can appear as self-confidence and self-content but it is, however, just a façade that hides narcissists' non-existing self-esteem. Self-centeredness also causes the lack of empathy. Human relationships are passionless and negligent. Narcissists did not seem to be able to create real intimate relationships that would be based on affection but they use other people by manipulating them (see also Keltinkangas-Järvinen, 1998).

"This negligence is as shuddering as can be. He/she does not feel empathy; not to mention that he/she could understand others' body language. " (Chassiel)

"He/she treats me TOTALLY like a thing, a commodity, does not even try to hide that I don't have any other value except the sexual one." (Rikottu [Broken])

A person with low self-esteem tolerates setbacks and hardships badly (Joutsiniemi et al., 2007). Indeed, narcissists appeared extremely thin-skinned: they tend to respond to criticism with a rapid counter-attack but in reality are deeply hurt. Criticism causes them shame that may follow and bother them for years. Shame also tells about their own imperfection and humanity (Malinen, 2007). To narcissists, it means the breakage of their own illusions of greatness and superiority.

Keeping up the facade is manifested by even ungovernable changes in moods and behavior. Their moods can alter from the deepest depression to arrogant supremacy and even to a manic state.

“Everything is fine as long as his/her things are fine.” (Pömppö)

"It is extremely difficult to avoid problems because the man changes his mind every day. Today he can solemnly announce that 'from this day we will always do like this' (for example put some object inside a certain closet). After a while, he has forgotten the whole thing and may become angry at me when I do exactly like he told me to do earlier (for example put that thing in that closet mentioned)." (Milla)

\subsection{Immorality}

The main category of immorality comprised lying, abuse, cheating, and vandalism. According to the data, narcissists seemed to understand moral as quite a changing and flexible concept. What is right in each situation 
Intimate relationship in the shadow of narcissism: What is like to live with a narcissistic spouse?

depends on what is serving them the best. Moral behavior calls for empathy and conscience that would regulate moral choices. Both of them appeared underdeveloped among narcissists (see also Välipakka \& Lehtosaari, 2007.)

"At the moment, I am not aware what things were true in our relationship and what were false..." (Lau80)

"For them, everyone is an object before anything. Sometimes rarely, even a tool if one might be useful but mostly just an object." (Daza)

Narcissists need other people to compensate their low self-esteem. These people, in this case their significant others, felt soon depleted when exploited for various narcissistic uses. Narcissists demand constant attention and admiration and received just from one person is not enough for long. Narcissists have to change people as the old ones lose their utility value. According to the data, narcissists cheat their spouses because they need undivided attention from several people. Narcissists lie about cheating, deny it and explain themselves in order not to lose the original source of attention; that is their spouse.

“There are plenty of nine days' wonders; the world is filled with new conquests." (Turvapaikka [Asylum])

"The man goes bananas every now and then during which he breaks things, smaller objects, a brush, pictures, an electric toothbrush, or bigger ones, such as a door or a wardrobe." (Assi)

\subsection{Lack of the sense of reality}

The main category of lack of the sense of reality comprised pathological jealousness, paranoia, and megalomania. Narcissists' sense of reality was blurred. They assume that everyone is like they are: envious, dishonest, and malevolent. Therefore, they cannot trust in anyone, not even in their own spouse. Furthermore, they are pathologically possessive to their spouses because they are afraid that their spouses cheat them - like they selves do. Narcissists cannot stand that their spouses spend time with other people. If they do, narcissists think that they are not good enough for their spouses.

"In addition, we had to be in contact all the time: awful number of text messages every day, meetings every day and good-night calls as well. In other words constant controlling." (Tsinnia)

"He/she doubts that the whole world is against him/her. Everyone steels from him/her... He/she is followed when coming back home. Someone has visited his/her apartment. Everyone lies. Everyone is envious of him/her." (Pömppö)

Setting goals may be quite unrealistic because narcissists are not aware or do not recognize their own strengths and weaknesses (Jaari, 2007). Illusions of omnipotence are common among small children but should disappear along age. Narcissists blow their own trumpet, overestimate their abilities, and brag openly. Fanatic feelings of one's own greatness and capability are not testimony of genuine self-confidence. Merely, they can be considered as assertion toward reality and denial of one's own limitedness. Narcissists cannot admit that they would fail in something.

"He did not have any money but still imagined that we would soon live abroad as millionaires... His plans would come and go.” (Leenajka) 
Määttä, M., Uusiautti, S., \& Määttä, K.

"-he/she who is, according to his/her own words, a god and deliberately difficult because

he/she is such a unique person that deserves only the best." (Pomppuli)

\subsection{Need for manipulation}

The main category of the need for manipulation covers discouragement, double bind communication, and histrionics. Narcissists try to keep up the illusion of their own excellence in order to hide their real feeling: envy that is directed to their significant other, victim. Narcissists seemed to become distressed because of others' success or achievements and perceive them as threats to their ego.

"In my opinion, double bind communication is manifested in our relationship by endless and harrowing harping, rotation of good and bad, overflowing provoking and eating one's words. At times, I really don't know the phase of our conversation." (OakLand)

\footnotetext{
"When being at the same time in the same place with the narcissist, there is no way you could do something your 'own' --- It is futile to even think of reading the paper, not to mention a book when the narcissist is nearby!" (Rikottu [Broken])
}

Narcissists want to nullify their victims in order to seem better in their own and others' eyes. They envy especially those admirable characteristics in their victims, such as authenticity, cheerfulness, openness, and honesty. They suppose that those skills and features are unachievable to them and thus subject to be rooted out from their victims as well.

"Laughing makes him/her hysterically furious. Joy has to be eliminated by one mean or another. You are not allowed to cry either.” (Pettuleipä [Bark bread])

Narcissists are dependent on their victim because their do not have the strength needed for bearing their weakness. Thus, narcissists need other people to admire them or bring some other concrete advantage.

\section{Discussion}

A person with narcissistic personality disorder is fixed and unchangeable. Narcissists are unable to act differently. A thought of a narcissist would change or change his/her behavior seems impossible as learning some new skill or behavioral model require admitting that he/she does not know it already. Neither can narcissists learn from mistakes because they do not admit their existence. Normally, the ego is a human being's best friend not an enemy. But narcissistic self-hate is deep. Narcissistic personality disorder can be seen the most serious dysfunction in self-esteem.

At the beginning, Vaknin's (1999) list of nine criteria for the diagnosis of narcissistic personality disorder was introduced. When comparing the results with these criteria, the congruence is evident. For example, when Vaknin refers to narcissists' high-flown illusions on their own greatness, in this research the term 'megalomania' was used for describing these delusions. Abuse occurs in both lists as were lack of empathy and selfishness. Vaknin states that narcissists envy other people and think it is reciprocal. In this research, narcissists' paranoia is brought out.

Yet, there are some differences between the lists as well. Vaknin's (1999) categorization does not include the exercise of power that was introduced in this research. For example, incrimination, subordination, intimidation, and physical violence were an apparent result in this research. However, Vakin's intention has been to compile a list that makes diagnosis easier while the focus in this research was in intimate relationships and how narcissists treat their spouses.

Before proceeding to conclusions, some reliability issues should also be brought out that concern this 
research. Researchers always have to ground their interpretations on the data and not on any random excerpts of it (Syrjälä \& Numminen, 1996). The data collection process and analysis are described in detail and the aim was to bring out the participants' voices and opinions. Of course, it is reasonable to ask to what extent the messages posted in the platform are selected and filtered. Indeed, the victims' stories represent a specific point of view: for example, not many positive things about narcissists were written on the platform. However, the purpose of the research was to study the victims' experiences and this seemed a suitable way as, for instance, interviewing them would have been practically impossible already because of the control narcissistic spouses have over them. In addition, messages in the platform do represent issues that the victims consider important and worth writing. From this point of view, the data can be seen reliable and truthful.

In this article, the purpose was to introduce narcissists' spouses' experiences and give space to their voices. In order to do that, we have added citations from the data to improve and support the transparency of the interpretations made in this research. Furthermore, the citations give a unique view to the concrete everyday life in the relationship with narcissists as it may be difficult to understand without any concrete examples.

\section{Conclusions}

The starting point of this research was to study intimate relationships in the shadow of narcissism. The purpose was to find out what it is like to live as a narcissist's spouse. The research showed that narcissism causes extensive problems and challenges in an intimate relationship. As the knowledge about the phenomenon increases, it will be possible to develop better ways to help narcissists who live in our society (Hare, 1993). Narcissists are extremely dependent on their intimate relationships and yet, they are particularly vulnerable to the threat of romantic rejection as their high levels of attachment anxiety are associated with low self-esteem (see Besser \& Priel, 2009).

The following conclusions can be drawn based on the research results:

1. In the intimate relationship, the narcissist is seen by his/her spouse as an unlimited, unstable, and immoral exerciser of power. The narcissistic spouse lacks the sense of reality and has a great need for manipulation. He/she also seems to have the ability to manipulate and thus causes a lot of pain to his/her spouse and other loved ones through hindering their growth and development.

2. Exercise of power in the intimate relationship covers incriminating, controlling, naming, and intimidating the victim. The narcissist rages and exercise physical violence. Due to maladjustment, the narcissist causes trouble in the relationship through his/her self-centeredness, moodiness, lack of empathy, and negligence. The narcissist does not tolerate criticism nor is capable of true intimacy. The narcissist's immorality is manifested in the intimate relationship by lying, infidelity, abusing the victim, and vandalism. Due to lack of the sense of reality, the narcissist is pathologically jealous, paranoid, and megalomaniac. The narcissist manipulates his/her victim. In the intimate relationship, it is shown as histrionics, discouragement, and double bind communication. The victim's possibilities to live full life become narrower and the opportunities to participate in societal developing actions become restricted - life with the narcissist appears as a prison.

3. Fundamentally, the narcissist suffers from difficult problems in self-esteem. Wide dysfunctions in the areas of self-esteem are perhaps the reason for the narcissist's behavior and trouble that follow.

Many features of narcissism can be seen as sources of success in the modern competitive society that is built on self-aggrandizement. The question is that to what extent the opportunistic abilities to bring out one's own proficiency and constantly strive for the better result in trample on other people and having an irresponsible and insensitive attitude to other people (see e.g. Lucher, Houston, Walker, \& Alex Houston, 2011). For example, it has been shown that narcissists tend to reduce the closeness of the relationship with someone if that someone outperforms themselves (Nicholls \& Stukas, 2011). Trzesniewski's and Donnellan's (2010) study showed that 
today's youngsters are less fearful of social problems than previous generations and they are also more cynical and less trusting. What does that trend mean for modern intimate relationships? At the same time, another research (see Uusiautti \& Määttä, 2010) brought out that having a family does not prevent one from having for example a successful career too: the readiness to make compromises and to take both of the spouse's hopes in the consideration appeared as the key factor. However, compromising does not seem to fit narcissistic behavior: narcissists' romantic attraction seems mostly as a strategy for enhancing self-esteem (Campbell, 1999). Therefore, it would be important to study how narcissists' self-esteem could be developed in a healthy way and toward healthy narcissism: that would not only benefit narcissists but also those people narcissists have influence over. One way of increasing awareness is through knowing and understanding the everyday life narcissists and their partners live - and that is the exact contribution of this article.

\section{References:}

Acock, A. C., Van Dulmen, M. H., Allen, K. R., \& Piercy, F. P. (2005). Contemporary and emerging research methods in studying families. In V. Bengtson, A. Acock, K. Allen, P. Dilworth-Anderson, \& D. Klein (Eds.), Sourcebook of family theory \& research (pp. 59-89). Thousand Oaks, CA: Sage.

Baumeister, R. F., Smart, L., \& Boden, J. M. (1996). Relation of threatened egotism to violence and aggression: The dark side of high self-esteem. Psychological Review, 103, 5-33.

Besser, A., \& Priel, B. (2009). Emotional responses to a romantic partner's imaginary rejection: the roles of attachment anxiety, covert narcissism, and self-evaluation. Journal of Personality, 77 (1), 287-325. doi:10.1111/j.1467-6494.2008.00546.x <http://dx.doi.org/10.1111/j.1467-6494.2008.00546.x>

Burton, J. P., \& Hoobler, J. M. (2011). Aggressive reactions to abusive supervision: The role of interactional justice and narcissism. Scandinavian Journal of Psychology, 52, 389-398. doi:10.1111/j.1467-9450.2011.00886.x <http://dx.doi.org/10.1111/j.1467-9450.2011.00886.x>

Campbell, W. K. (1999). Narcissism and romantic attraction. Journal of Personality and Social Psychology, 77(6), 1254-1270.

Carlson, E. N., Vazire, S., \& Oltmanns, T. F. (2011). You probably think this paper's about you: Narcissists' perceptions of their personality and reputation. Journal of Personality and Social Psychology, 101(1), 185-201. doi:10.1037/a0023781 <http://dx.doi.org/10.1037/a0023781>

Crompton, S. (2007). All about me: Loving a narcissist. London: HarperCollins.

Ellilä, T. (2008). Jätä sääli ja pakene, tai narsisti vie sinut hulluuden partaalle [Leave the pity and run-or the narcissist makes you lose your mind]. Retrieved November 9, 2009 from http://www.aamulehti.fi/teema/terveys/58260.shtml

England, D. (2007). Here's how narcissism and narcissistic personality disorder, plus antisocial personality and antisocial personality disorder, relate to domestic violence. Retrieved November 24, 2009 from http://www.narcissismaddictionsabuse.com/Narcissistic\%20Personality\%20Disorder\%20and\%20Anris ocial\%20Personality\%20Disorder\%20and\%20Domestic\%20Violence.html

Fan, Y., Wonneberger, C., Enzi, B., de Greck, M., Ulrich, C., Tempelmann, C., Bogerts, B., Doering, S., \& Northoff, G. (2010). The narcissistic self and its psychological and neural correlates: an exploratory fMRI study. Psychological Medicine, 41, 1641-1650. doi:10.1017/S003329171000228X <http://dx.doi.org/10.1017/S003329171000228X>

Forward, S., \& Torres, J. (1989). Miehet, jotka vihaavat naisia. Naiset, jotka rakastavat heitä [Men who hate women. Women who love them]. (Transl. by M. Rutanen.) Espoo: WSOY.

Freud, S. (1993). Johdatus narsismiin ja muita esseitä [Introduction to narcissism and other essays]. (Transl. by M. Rutanen). Jyväskylä: Gummerus.

Geist, R. A. (2009). Empathic understanding: the foundation of self-psychological psychoanalysis.

Annals of the New York Academy of Sciences, 1159(1), 63-74. doi: 0.1111/j.1749-6632.2009.04353.x <http://dx.doi.org/0.1111/j.1749-6632.2009.04353.x>

Gosling, S. D., John, O. P., Craik, K. H., \& Robins, R. W. (1998). Do people know how they behave? Self-reported act frequencies compared with on-line codings by observers. Journal of Personality and 
Intimate relationship in the shadow of narcissism: What is like to live with a narcissistic spouse?

Social Psychology, 74, 1337-1349. doi:10.1037/0022-3514.74.5.1337

$<$ http://dx.doi.org/10.1037/0022-3514.74.5.1337>

Greenberg, J. (2008). Understanding the vital human quest for self-esteem. Perspectives on Psychological

Science, 3(1), 48-55. doi:10.1111/j.1745-6916.2008.00061.x

$<$ http://dx.doi.org/10.1111/j.1745-6916.2008.00061.x>

Hare, R. D. (1993). Ilman omaatuntoa [Without conscience]. (Transl. by V. Kiuru \& P. Haapoja.) Keuruu: Otava.

Hartmann, H. P. (2009). Psychoanalytic self psychology and its conceptual development in light of developmental psychology, attachment theory, and neuroscience. Annals of the New York Academy of Science, 1159, 86-105.

Holtzman, N. S., Vazire, S., \& Mehl, M. R. (2010). Sounds like a narcissist: Behavioral manifestations of narcissism in everyday life. Journal of Research in Personality, 44(4), 478-484. doi:

10.1016/j.jrp.2010.06.001 <http://dx.doi.org/10.1016/j.jrp.2010.06.001>

Hotchkiss, S. (2005). Miksi aina sinä? Narsismin seitsemän syntiä [Why always you? Seven sins of narcissism]. (Transl. by R. Viitanen.) Helsinki: Gummerus.

Jaari, A. (2007). Kylliksi itselleni [Enough for me]. Helsinki: Edita.

Joutsiniemi, M., Kaulio, P., Mäkelä, R., Pekola, J., \& Schulman, G. (2007). Naimisissa narsistin kanssa [Married to a narcissist]. Jyväskylä: Gummerus.

Keltinkangas - Järvinen, L. (1978). Väkivalta ja itsetuho [Violence and self-destruction]. Keuruu: Otava.

Keltinkangas - Järvinen, L. (1985). Aggressiivinen lapsi. Miten ohjata lapsen persoonallisuuden kehitystä [An aggressive child. How to guide a child's personality development?] Keuruu: Otava.

Keltinkangas - Järvinen, L. (1998). Hyvä itsetunto [Good self-esteem]. Juva: WSOY.

Kiviniemi, K. (2001). Laadullinen tutkimus prosessina [Qualitative research as a process]. In J. Aaltola \& R. Valli (Eds.), Ikkunoita tutkimusmetodeihin 2. Näkökulmia aloittelevalla tutkijalle tutkimuksen teoreettisiin lähtökohtiin ja analyysimenetelmiin [Introduction to research methods II. Perspectives into theoretical foundations and analysis methods for beginning researchers] (pp. 68-84). Jyväskylä: Gummerus.

Luchner, A. F., Houston, J. M., Walker, C., \& Alex Houston, M. M. (2011). Exploring the relationship between two forms of narcissism and competitiveness. Personality \& Individual Differences, 51(6), 779-782. doi:10.1016/j.paid.2011.06.033 <http://dx.doi.org/10.1016/j.paid.2011.06.033>

Malinen, B. (2007). Häpeän monet kasvot [The many faces of shame]. Jyväskylä: Gummerus.

Myllärniemi, J. (2005). Onko narsismi sairaus? [Is narcissism a disease?] Retrieved March 4, 2008 from http://www.jotte.info/narsismi/index.html

Määttä, M. (2009). "Nyt katson koko maailman pahuutta suoraan silmiin" Parisuhde narsismin varjossa ["Now, I'm looking at the evilness of the world in the eye" An intimate relationship in the shadow of narcissism]. Unpublished masteral thesis, University of Lapland, Rovaniemi, Finland.

Nicholls, E., \& Stukas, A. A. (2011). Narcissism and the self-evaluation maintenance model: effects of social comparison threats on relationship closeness. Journal of Social Psychology, 151(2), 201-212. doi: 10.1080/00224540903510852 <http://dx/doi.org/10.1080/00224540903510852>

Penney, L. M., \& Spector, P. E. (2002). Narcissism and counterproductive work behavior: Do bigger egos mean bigger problems? International Journal of Selection and Assessment, 10, 126-134.

Schulman, G. (2005a). Narsismin yleisyys ja sen päällekkäisyys muihin persoonallisuushäiriöihin verrattuna [The frequency of narcissism and overlap with other personality disorders]. Retrieved September 30, 2009 from http://www.narsistienuhrientuki.info/index.php?valikko=3\&alasivu=212

Schulman, G. (2005b). Narsismi ja itsemurha [Narcissism and suicide]. Retrieved September 30, 2009 from: http://www.narsistienuhrientuki.info/index.php?valikko=3\&alasivu=224

Trzesniewski, K. H., \& Donnellan, M. B. (2010). Rethinking "Generation Me": A study of cohort effects from 1976-2006. Perspectives on Psychological Science, 5(1), 58-75. doi:10.1177/1745691609356789 $<$ http://dx.doi.org/10.1177/1745691609356789>

Tuomi, J., \& Sarajärvi, A. (2002). Laadullinen tutkimus ja sisällönanalyysi [Qualitative research and content analysis]. Jyväskylä: Gummerus. 
Määttä, M., Uusiautti, S., \& Määttä, K.

Uusiautti, S., \& Määttä, K. (2010, accepted). The successful combination of work and family in Finland: The ability to compromise as a key factor. Journal of Comparative Family Studies.

Vaknin, S. (1999). Ilkeä itserakkaus. Narsismin kuva [Nasty self-love. The picture of narcissism]. Retrieved October 1, 2009 from http://www.healingeagle.net/Fin/Vaknin/Vaknin.html

Vuorinen, R. (1998). Minän synty ja kehitys [The birth and development of self]. Porvoo: WSOY.

Välipakka, T., \& Lehtosaari, A. (2007). Sata tapaa tappaa sielu. Narsismin uhrit kertovat [Hundred ways of killing the soul told by the victims of narcissism]. Vantaa: Gummerus.

Watson, P. J., Sawrie S. M., Greene, R. L., \& Arredondo, R. (2002). Narcissism and depression: MMPI-2 evidence for the continuum hypothesis in clinical samples. Journal of Personality Assessment, 79, 85-109.

Žvelc, G. (2010). Object and subject relations in adulthood - towards an integrative model of interpersonal relationships. Psychiatria Danubina, 22(4), 498-508. 